\title{
Formation and Reversion of Streptomycete Protoplasts: Cultural Condition and Morphological Study
}

\author{
By M. OKANISHI, K. SUZUKI AND H. UMEZAWA \\ Department of Antibiotics and Department of Chemistry, National Institute \\ of Health, Kamiohsaki, Shinagawa-ku, Tokyo, Japan
}

(Received I 2 June 1973; revised 3 September 1973)

\begin{abstract}
SUMMAR Y
Cultural conditions for forming and stabilizing protoplasts of Streptomyces griseus and $S$. venezuelae were studied by reference to the number of protoplasts formed, leakage from protoplasts and reversion rate. Effective formation and stabilization of the protoplasts was accomplished by using a hypertonic medium containing Io mM-MgCl 2 and $25 \mathrm{mM}_{-} \mathrm{CaCl}_{2}$. Electron microscopy showed that the protoplasts of $S$. griseus, when prepared in the above medium, formed vesicles on the cytoplasmic membrane or out of the protoplasts, but when prepared in a medium with $3 \mathrm{~mm}-\mathrm{MgCl}_{2}$ and $3 \mathrm{~mm}-\mathrm{CaCl}_{2}$ they provided few such vesicles.

The reversion of protoplasts to the normal filamentous state was examined by the growth on various synthetic agar media. A high reversion rate was obtained by incubating the protoplasts on a hypertonic agar medium containing 20 or 50 mM- $\mathrm{MgCl}_{2}, 50$ or $20 \mathrm{mM}-\mathrm{CaCl}_{2}, 0.44$ or $0.22 \mathrm{~mm}$-phosphate and $0.0 \mathrm{I} \%$ Casamino acids. Combinations of appropriate concentrations of $\mathrm{MgCl}_{2}$ and $\mathrm{CaCl}_{2}$ were significantly effective in the reversion as well as in the stability of protoplasts. The concentration of phosphate should be adjusted to 0.44 or $0.22 \mathrm{~mm}$. Casamino acids enhanced both growth and reversion rates.

The reversion of protoplasts of Streptomyces griseus was followed by using phase-contrast microscopy. The protoplasts incubated on medium RI enlarged to about $40 \mu \mathrm{m}$ and then generated filamentous hyphae from the periphery.
\end{abstract}

\section{INTRODUCTION}

Transfection of actinophage DNA to protoplasts of Streptomyces kanamyceticus was reported previously (Okanishi, Utahara \& Okami, I966; Okanishi, Hamana \& Umezawa, 1968). However, in order to study the genetic transformation with protoplasts of streptomycetes in more detail, it was required to establish the cultural conditions for preparing protoplasts and for reverting them to the normal filamentous state.

Formation of streptomycete protoplasts has been observed by several investigators (Douglas, Robinson \& Corke, I958; Bradley, 1959; Kochkina \& Rautenshtein, I968). Sagara et al. (197I) reported that the mycelia of Streptomyces griseoflavus grown in a high glycine concentration medium were sensitive to lysozyme action and that the protoplasts formed lost mesosomes. Recently, they mentioned that only a small fraction of protoplasts could be reverted by embedding them in a stabilized thin layer agar and then overlaying hypertonic Sabouraud's broth (Sagara, Fukui, Ota, Kashiyama, Fujimoto \& Yoshida, at the 43rd Annual Meeting of the Japanese Bacteriological Society, 1970).

In this paper, we report the cultural conditions for preparing stable protoplasts of streptomycetes and for reverting them to the filamentous state at a high frequency on the surface 
Table I. Media for preparing and reverting streptomycete protoplasts

Ingredient
Sucrose (g)
$\mathrm{K}_{2} \mathrm{SO}_{4}(\mathrm{~g})$
$\mathrm{Trace} \mathrm{Clement}^{*}$ solution $(\mathrm{ml})$
$\mathrm{KH}_{2} \mathrm{PO}_{4}^{*}(\mathrm{~g})$
$\mathrm{MgCl}_{2} \cdot 6 \mathrm{H}_{2} \mathrm{O}(\mathrm{g})$
$\mathrm{CaCl}_{2} \cdot 2 \mathrm{H}_{2} \mathrm{O}^{*}(\mathrm{~g})$
$\mathrm{Glucose}_{(\mathrm{g})}$
L-Asparagine (g)
L-Proline* (g)
Casamino acids (g)
O-25 M-TES buffer,* pH $7 \cdot 2$ (ml)
Agar, powdered (g)
Total volume with distilled water (l)

\begin{tabular}{|c|c|c|}
\hline \multicolumn{3}{|c|}{ Medium } \\
\hline $\mathbf{P}$ & $\mathrm{R}_{\mathrm{I}}$ & R2 \\
\hline 103 & I03-I 7I & $103-171$ \\
\hline$(0.3 \mathrm{M})$ & $(0.3-0.5 \mathrm{M})$ & $(0.3-0.5 \mathrm{M})$ \\
\hline 0.25 & 0.25 & 0.25 \\
\hline 2 & 2 & 2 \\
\hline 0.05 & 0.05 & 0.05 \\
\hline 2.03 & 4.07 & $10 \cdot 12$ \\
\hline$(0.01 \mathrm{M})$ & $(0.02 \mathrm{M})$ & $(0.05 \mathrm{M})$ \\
\hline $\begin{array}{c}3.68 \\
(0.025 \mathrm{M})\end{array}$ & $\begin{array}{c}7.37 \\
(0.05 \mathrm{M})\end{array}$ & $\begin{array}{c}2.95 \\
(0.02 \mathrm{M})\end{array}$ \\
\hline - & 10 & IO \\
\hline 一 & 2 & - \\
\hline 一 & - & 3 \\
\hline 一 & $O \cdot I$ & 0.1 \\
\hline 100 & 100 & 100 \\
\hline- & 22 & 22 \\
\hline I & I & I \\
\hline
\end{tabular}

Trace element solution (per litre): $\mathrm{ZnCl}_{2}, 40 \mathrm{mg} ; \mathrm{FeCl}_{3} .6 \mathrm{H}_{2} \mathrm{O}, 200 \mathrm{mg} ; \mathrm{CuCl}_{2} .2 \mathrm{H}_{2} \mathrm{O}$, Io mg; $\mathrm{MnCl}_{2}$. $4 \mathrm{H}_{2} \mathrm{O}$, IO mg; $\mathrm{Na}_{2} \mathrm{~B}_{4} \mathrm{O}_{7} . \mathrm{IOH}_{2} \mathrm{O}$, IO $\mathrm{mg}$; and $\left(\mathrm{NH}_{4}\right)_{6} \mathrm{Mo}_{24} \cdot 4 \mathrm{H}_{2} \mathrm{O}$, $10 \mathrm{mg}$.

* Sterilized separately.

of synthetic agar plates. The morphology of protoplasts shown by electron microscopy, and their reversion process studied by phase-contrast microscopy, are also described.

\section{METHODS}

Organisms and cultivation. Streptomyces griseus ISP5236 and S. venezuelae ISP5230 were used throughout the experiments. They were shake-cultured at $28{ }^{\circ} \mathrm{C}$ for 2 days in medium $\mathrm{S}$ consisting of $(\mathrm{g} / \mathrm{l})$ : glucose, ro; peptone, 4; yeast extract (Difco Laboratories, Detroit, Michigan, U.S.A.), $4 ; \mathrm{MgSO}_{4} \cdot 7 \mathrm{H}_{2} \mathrm{O}, 0.5 ; \mathrm{KH}_{2} \mathrm{PO}_{4}, 2 ; \mathrm{K}_{2} \mathrm{HPO}_{4}, 4 ;$ and distilled water to I 1. The culture was transferred to fresh medium $\mathrm{S}$ supplemented with glycine $(0.8 \%$, $\mathrm{w} / \mathrm{v}$, in $S$. griseus and $2 \%, \mathrm{w} / \mathrm{v}$, in $S$. venezuelae, based on sensitivity to glycine concentration), and shake-cultured until the middle of exponential phase. The mycelia were harvested by centrifugation and washed with a solution of $0.3 \mathrm{M}$-sucrose.

Preparation of protoplasts. Unless otherwise stated, the washed mycelia were incubated in medium P (Table I) containing I mg of lysozyme/ml (grade I, Sigma Chemical Co., Missouri, U.S.A.) and $100 \mu \mathrm{g}$ of Lytic enzyme no. $2 / \mathrm{ml}$ (supplied by Kyowa Hakko Kogyo Co., Tokyo, Japan) at $32{ }^{\circ} \mathrm{C}$ for I to $2 \mathrm{~h}$. When mycelia in the reaction fluid ceased to be visible under the microscope, the suspension was filtered through cotton and then through a Nuclepore filter ( $5 \mu \mathrm{m}$ pore size, General Electric Co., U.S.A.) to exclude mycelial forms. The filtered protoplasts were washed three times with cold medium $P$, by means of centrifugation at 1000 or I $500 \mathrm{~g}$ for I $5 \mathrm{~min}$. The number of protoplasts was counted by a haemocytometer under a phase-contrast microscope.

Leakage from protoplasts during preparation. The enzyme-treated mycelial suspension was centrifuged at $7000 \mathrm{~g}$ for $15 \mathrm{~min}$ to remove protoplasts and cell debris. Leakage was expressed as the percentage increase in light absorption at $260 \mathrm{~nm}\left(E_{260}\right)$ in the supernatant fluid, taking the increase in $E_{260}$ in the completely lysed fluid without the addition of sucrose 
and divalent cations as $100 \%$. The value obtained indicates the relative release of soluble nucleotides and nucleic acid which have leaked out of protoplasts or which have been released by some disruption of cells (Reaveley \& Rogers, 1969).

Reversion of protoplasts. A suspension of the purified protoplasts was diluted with medium $\mathrm{P}$ to a level of $10^{4} / \mathrm{ml}$, and $0.05 \mathrm{ml}$ of the dilution was spread on a plate of various synthetic agar media with a glass rod. The plates were incubated at $28^{\circ} \mathrm{C}$ after drying the surfaces at room temperature. Growing colonies were counted and the reversion rate was expressed as the percentage of the total number of protoplasts which inoculated.

Electron microscopy. Prefixation of specimens was carried out by a modification of the method of Ghosh \& Murray (1967). Specimens were suspended in a medium E consisting of $0.4 \mathrm{M}$-sucrose, I.435 $\mathrm{mM}_{2} \mathrm{~K}_{2} \mathrm{SO}_{4}, 0.02 \mathrm{M}-\mathrm{MgCl}_{2}, 0.05 \mathrm{M}-\mathrm{CaCl}_{2}$, and $0.05 \mathrm{M}$-TES buffer (Good et al. 1966), $\mathrm{pH} 6.5$. They were prefixed by adding glutaraldehyde at a concentration of $6 \%(\mathrm{v} / \mathrm{v})$, allowed to stand for $2 \mathrm{~h}$ in the cold and washed with medium $\mathrm{E}$, followed by centrifugation. Subsequently, they were prefixed by adding osmium tetroxide $(0.5 \%)$, allowed to stand overnight in a refrigerator, and then washed with medium $\mathrm{E}$, followed by centrifugation. These specimens were suspended in warm agar $\left(45^{\circ} \mathrm{C}, 2 \% \mathrm{v} / \mathrm{v}\right.$, in medium E) and allowed to solidify. The agar block was then cut on a glass slide into pieces approximately I mm square. The pieces were dehydrated with ethanol and were embedded in epoxy resin. Sections were cut with an LKB 4800 ultra-microtome with a diamond knife, stained with lead hydroxide and uranyl acetate, and examined with an HS-8 electron microscope (Hitachi, Japan).

\section{RESULTS}

\section{Formation and stability of protoplasts}

In preliminary experiments, the following results were obtained: some species of streptomycetes (e.g. Streptomyces venezuelae, S. kanamyceticus, S. hygroscopicus and whorlforming streptomycetes) were lysed with lysozyme only after incubation in the presence of glycine, as noted by Sagara et al. (1971); mycelia harvested from the stationary phase, even in the presence of glycine, were hardly lysed with lysozyme and Lytic enzyme no. 2; a solution of sucrose at a concentration of more than $0.35 \mathrm{M}$, in the presence of divalent cations, inhibited the enzymic formation of protoplasts. Therefore, streptomycetes were incubated in medium $\mathrm{S}$, containing glycine. The mycelia at the middle of the exponential phase of growth were harvested, washed with a solution of $0.3 \mathrm{M}$-sucrose and treated with lysozyme and Lytic enzyme no. 2 in a solution containing $0.3 \mathrm{M}$-sucrose.

The effects of $\mathrm{Na}^{+}, \mathrm{Mg}^{2+}$ and $\mathrm{Ca}^{2+}$ on the formation and leakage of protoplasts were tested by suspending the washed mycelia of Streptomyces griseus and $S$. venezuelae in various test fluids, and by incubating with the enzymes at $30^{\circ} \mathrm{C}$ until the mycelial forms became undetectable under phase-contrast microscopy. The number of protoplasts formed was counted and the leakage of protoplasts was determined. In S. griseus, the absence of $\mathrm{MgCl}_{2}$ and $\mathrm{CaCl}_{2}$ in the tested hypertonic fluid resulted in the formation of only a small number of protoplasts and considerable leakage. An equivalent amount of leakage was observed when control solutions lacking sucrose and divalent cations were used; such conditions resulted in complete lysis. The presence of $\mathrm{MgCl}_{2}$ and $\mathrm{CaCl}_{2}$ at a level of $3 \mathrm{mM}$ or more, irrespective of the presence of $\mathrm{NaCl}$, allowed the formation of numerous protoplasts and prevented the leakage (Table 2). In $S$. venezuelae, on the other hand, formation of the protoplasts and the amount of leakage were not affected by the presence of divalent cations in the tested fluid (Table 2).

When protoplasts of Streptomyces griseus were prepared in a hypertonic fluid containing 
Table 2. Effect of $\mathrm{Na}^{+}, \mathrm{Mg}^{2+}$, and $\mathrm{Ca}^{2+}$ on the formation of protoplasts

\begin{tabular}{|c|c|c|}
\hline \multicolumn{3}{|c|}{$\begin{array}{l}\text { Salts (mM) added to basal } \\
\text { medium* }\end{array}$} \\
\hline $\mathrm{NaCl}$ & $\mathrm{MgCl}_{2}$ & $\mathrm{CaCl}_{2}$ \\
\hline 70 & $-\rightarrow$ & - \\
\hline 70 & 3 & 3 \\
\hline - & 3 & 3 \\
\hline- & 25 & 10 \\
\hline 一 & 10 & 25 \\
\hline
\end{tabular}

\begin{tabular}{|c|c|}
\hline \multicolumn{2}{|c|}{$\begin{array}{c}\text { Streptomyces griseus } \\
\text { ISP5236 }\end{array}$} \\
\hline $\begin{array}{l}\text { Protoplasts } \\
\text { (no. } / \mathrm{ml} \text { ) }\end{array}$ & $\begin{array}{l}\text { Leakage } f \\
(\%)\end{array}$ \\
\hline$<\mathrm{IO}^{5}$ & IO4 \\
\hline $12 \times 10^{8}$ & I3 \\
\hline $14 \times 10^{8}$ & 7 \\
\hline $12 \times 10^{8}$ & 15 \\
\hline $15 \times 10^{8}$ & 13 \\
\hline
\end{tabular}

$\begin{array}{cc}\begin{array}{c}\text { Streptomyces venezuelae } \\ \text { Protoplasts } \\ \text { (no. } / \mathrm{ml})\end{array} & \begin{array}{c}\text { Leakage } \dagger \\ (\%)\end{array} \\ \mathrm{I} 8 \times 10^{8} & \mathrm{I3} \\ \mathrm{ND} & \mathrm{ND} \\ 6 \times 10^{8} & \mathrm{I2} \\ 15 \times 10^{8} & 22 \\ 17 \times 10^{8} & 17\end{array}$

* Basal medium (per litre): sucrose, $103 \mathrm{~g} ; \mathrm{K}_{2} \mathrm{SO}_{4}, 0.25 \mathrm{~g}$; trace element solution, $2 \mathrm{ml} ; \mathrm{KH}_{2} \mathrm{PO}_{4}$, $0.05 \mathrm{~g}$; and $0.25 \mathrm{M}$-TES buffer $(\mathrm{pH} 7 \cdot 2), 100 \mathrm{ml}$.

$\dagger$ Leakage was expressed as the percentage increase in light absorption at $260 \mathrm{~nm}\left(E_{260}\right)$ in the supernatant fluid; as a reference, the increase of $E_{260}$ in completely lysed suspensions without the addition of sucrose and divalent cations was designated as $100 \%$.

ND, not done.

Table 3. Effect of various salts on the stability of Streptomyces griseus protoplasts in suspension

Salts (mM) added to basal medium*

$\begin{array}{ccc}\mathrm{NaCl} & \mathrm{MgCl}_{2} & \mathrm{CaCl}_{2} \\ 70 & - & - \\ 70 & 3 & 3 \\ - & 3 & 3 \\ - & 25 & 10 \\ - & 10 & 25 \\ - & 10 & 25\end{array}$

$\begin{array}{cc}\text { Incubation at } & \text { Stability } \\ 28^{\circ} \mathrm{C} \text { for I h } & (\%) \\ + & 2 \\ + & 79 \\ + & 65 \\ + & 86 \\ + & 96 \\ - & 100\end{array}$

* Basal medium: see the legend to Table 2.

$\uparrow$ The stability of the protoplasts diluted with various hypertonic fluids was examined by determining the reversion rate. Stability was expressed as the relative percentage of regeneration, with respect to the regeneration rate of the protoplasts plated directly without incubation in medium P. Medium RI (see Table I) was used for regeneration.

$3 \mathrm{mM}-\mathrm{MgCl}_{2}$ and $3 \mathrm{mM}-\mathrm{CaCl}_{2}$, however, these protoplasts were unstable and most of them were disrupted during purification by centrifugation. Furthermore, the reversion rate from the purified protoplasts was low. Therefore the stability of the protoplasts diluted with various hypertonic fluids was examined by determining the reversion rate. A suspension of the purified protoplasts, which were formed in a hypertonic fluid containing $10 \mathrm{mM}-\mathrm{MgCl}_{2}$ and $25 \mathrm{mM}_{-} \mathrm{CaCl}_{2}$, was diluted with various hypertonic media, incubated at $28{ }^{\circ} \mathrm{C}$ for $\mathrm{I} \mathrm{h}$, spread on an agar plate and incubated. As shown in Table 3, protoplasts were observed to be labile in suspensions at low concentrations of $\mathrm{MgCl}_{2}$ and $\mathrm{CaCl}_{2}$ in the hypertonic fluid, and the highest stabilities were obtained in medium $\mathrm{P}$ containing $10 \mathrm{mM}-\mathrm{MgCl}_{2}$ and 25 mM- $\mathrm{CaCl}_{2}$ (Table I).

\section{Electron microscopy of protoplasts}

Presence or absence of a wall layer and mesosomes was studied in thin sections of intact mycelia and protoplasts of Streptomyces griseus. In the sections of intact mycelium, a wall layer $20 \mathrm{~nm}$ thick and mesosomes of a lamella-like structure were observed (Fig. I $a, b$ ). In the protoplasts formed by low concentrations of the divalent cations $(3 \mathrm{~mm})$, neither a 

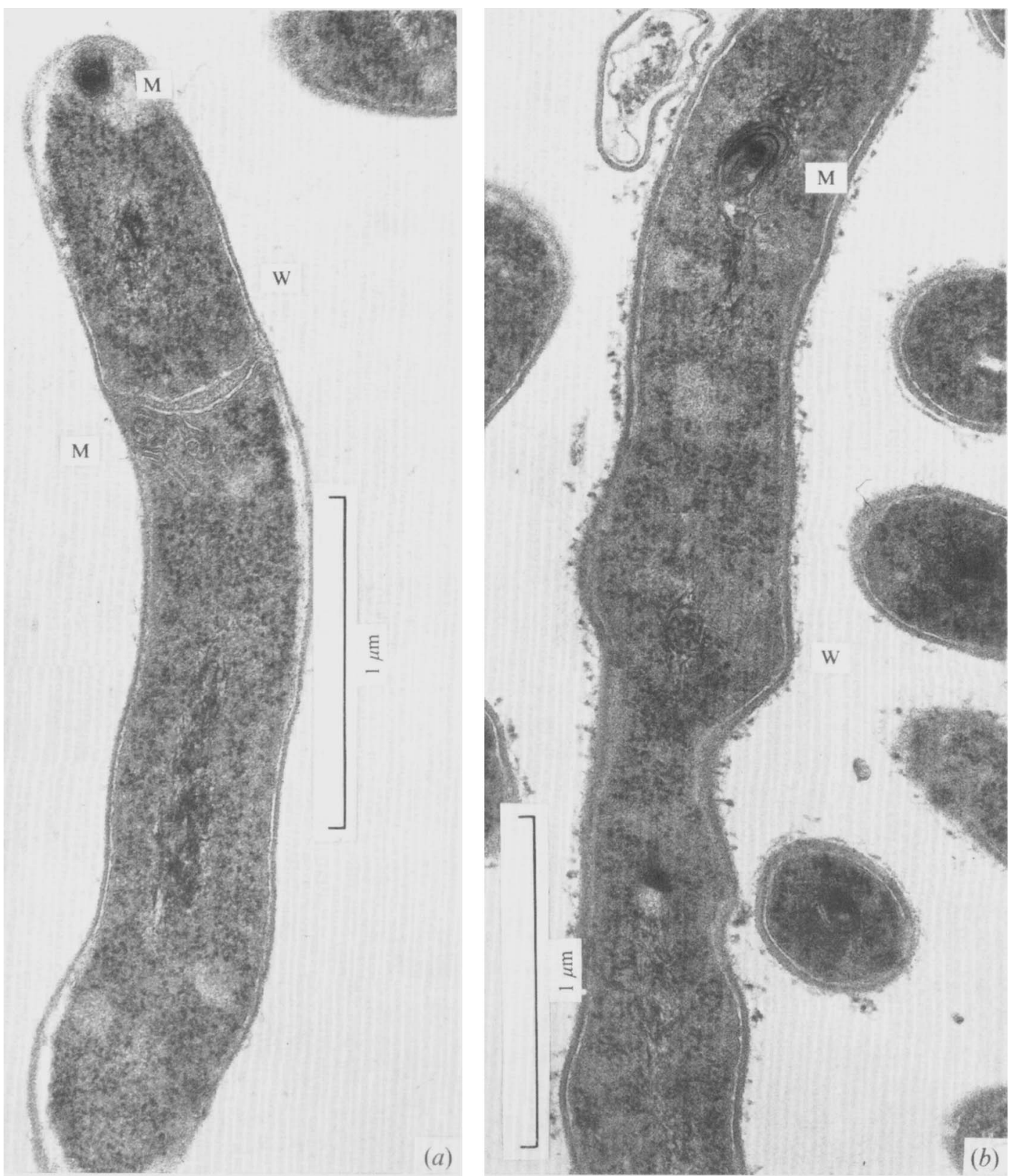

Fig. 1. Sections of the substrate mycelium of Streptomyces griseus prior to the treatment with lysozyme and Lytic enzyme no. 2. W, wall; $M$, mesosome.

wall layer nor mesosomes of a lamella-like structure was observed, and vesicles, attached to or released from the cytoplasmic membrane, were rarely seen (Fig. 2). In the protoplasts formed by higher concentrations of cations ( $\mathrm{IO} \mathrm{mM}-\mathrm{MgCl}_{2}$ and $25 \mathrm{mM}-\mathrm{CaCl}_{2}$ ), the absence of a wall layer and mesosomes was also demonstrated but some vesicles, possibly derived from mesosomes, were observed outside the cytoplasmic membrane (Fig. 3). The presence 


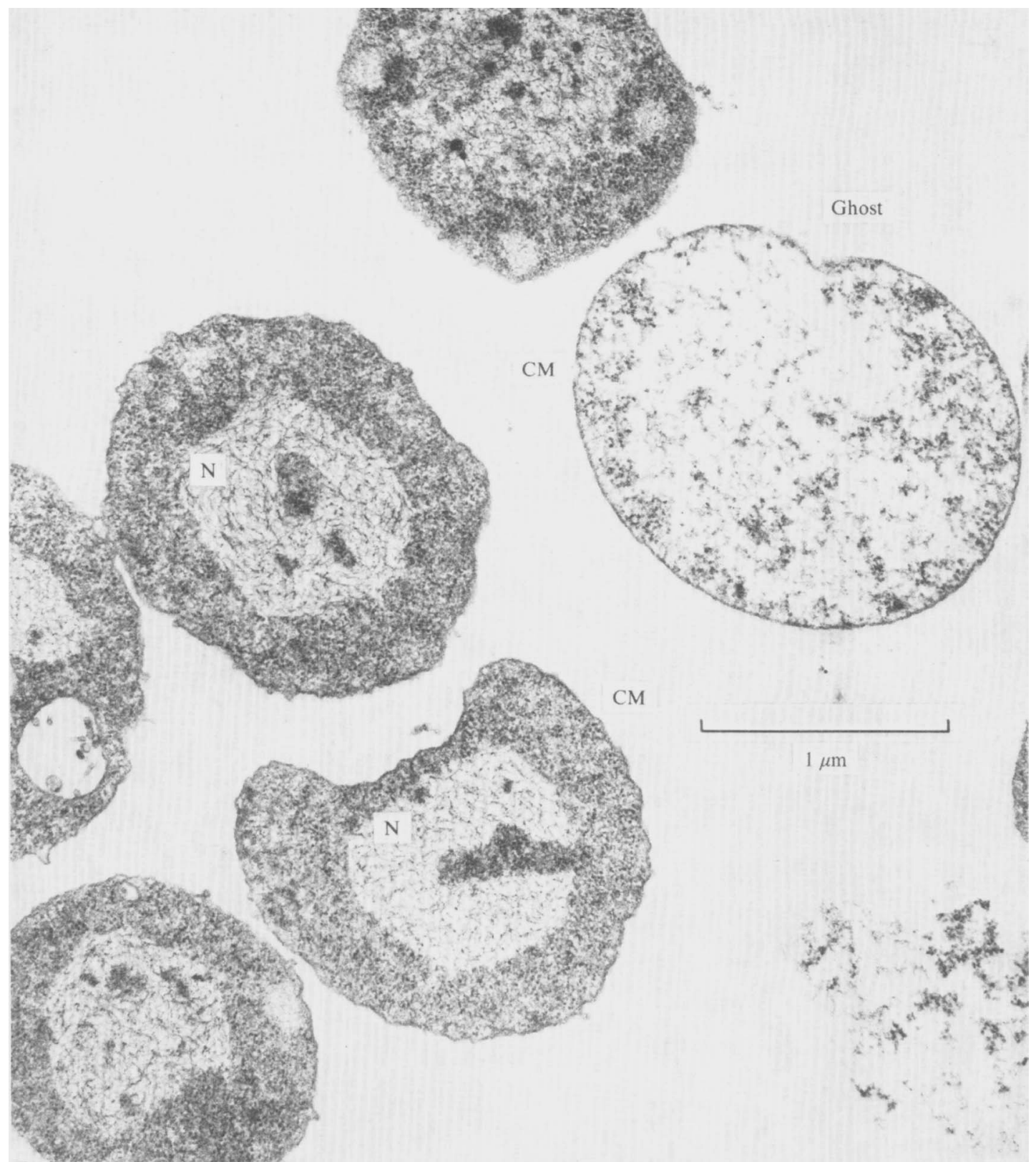

Fig. 2. Section of Streptomyces griseus protoplasts formed by enzymes with a combination of 3 $\mathrm{mM}-\mathrm{MgCl}_{2}$ and $3 \mathrm{~mm}-\mathrm{CaCl}_{2}$ in the hypertonic fluid. Typical vesicles are rarely seen. CM, cytoplasmic membrane; $\mathrm{N}$, nuclear region.

or absence of the vesicles, depending on the procedures for preparing protoplasts, was reproducible.

\section{Reversion of protoplasts}

Various synthetic agar media were used to study reversion of protoplasts to the normal filamentous state. Preliminary experiments showed that reversion on agar was significantly 


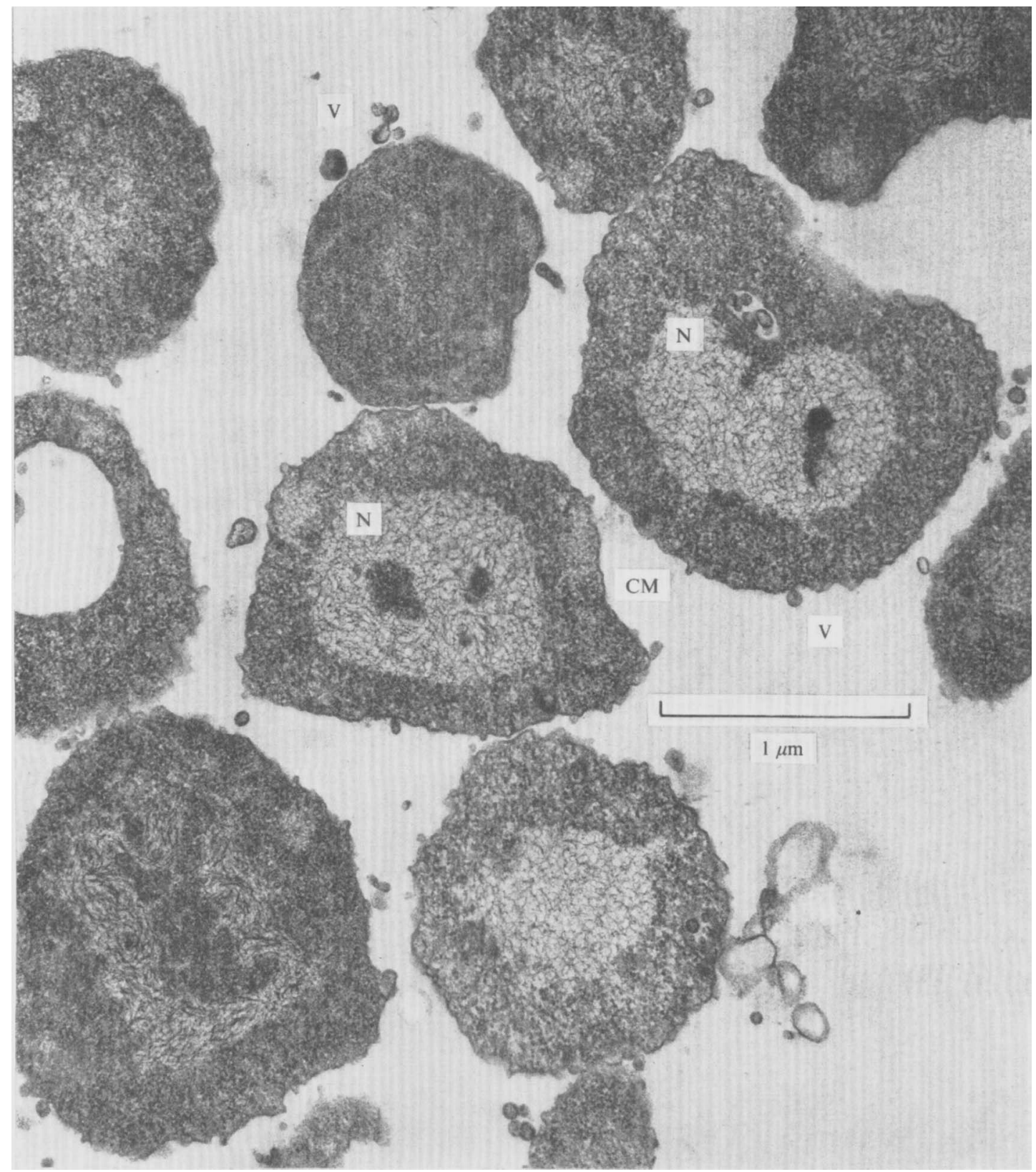

Fig. 3. Section of Streptomyces griseus protoplasts formed by enzymes in combination with Io $\mathrm{mm}-\mathrm{MgCl}_{2}$ and $25 \mathrm{~mm}-\mathrm{CaCl}_{2}$ in the hypertonic fluid. Some vesicles are still attached to the cytoplasmic membrane; others may be released from the membrane. CM, cytoplasmic membrane; $\mathrm{N}$, nuclear region; $\mathrm{V}$, vesicles. 

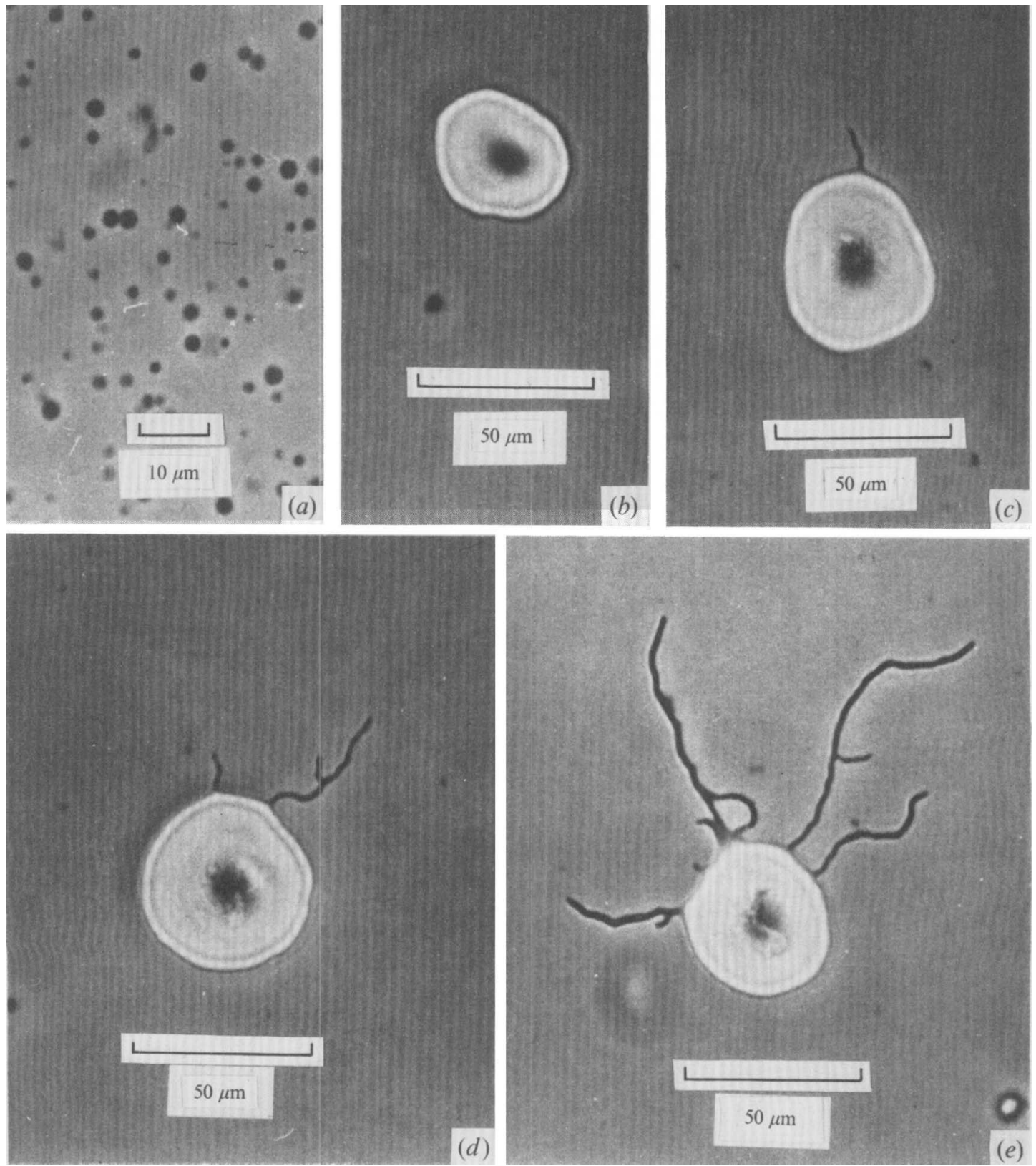

Fig. 4. Reverting process of Streptomyces griseus protoplasts on medium R $\mathrm{I}$, under phase-contrast microscopy. (a) Suspension of protoplasts; (b) $40 \mathrm{~h}$ after incubation; $(c)$ and $(d), 48 \mathrm{~h}$ after incubation; (e) $65 \mathrm{~h}$ after incubation.

affected by the concentration of $\mathrm{MgCl}_{2}, \mathrm{CaCl}_{2}$, phosphate and Casamino acids as well as by the concentration of sucrose, the nature of the nitrogen source and the type of buffer. The effects of $\mathrm{Mg}^{2+}, \mathrm{Ca}^{2+}$, phosphate and Casamino acids on the reversion rate were therefore examined (Table 4 ). $\mathrm{MgCl}_{2}$ and $\mathrm{CaCl}_{2}$ at a concentration of $3 \mathrm{mM}$ each did not allow protoplasts of Streptomyces griseus and $S$. venezuelae to revert. Increasing the $\mathrm{CaCl}_{2}$ 
Table 4. Effect of various chemicals on regeneration of the normal filamentous state from protoplasts

$\begin{array}{ccccc}\mathrm{M}_{\mathrm{MgCl}_{2}} & \begin{array}{c}\mathrm{CaCl} \\ (\mathrm{mM})\end{array} & \begin{array}{c}\mathrm{PPB} \dagger \\ (\mathrm{mM})\end{array} & \begin{array}{c}\mathrm{KCl} \\ (\mathrm{mM})\end{array} & \begin{array}{c}\text { Casamino } \\ \text { acids } \\ (\%)\end{array} \\ 3 & 3 & 0.22 & - & 0.0 \mathrm{I} \\ 3 & 60 & 0.22 & - & 0.0 \mathrm{I} \\ 60 & 3 & 0.22 & - & 0.0 \mathrm{I} \\ 20 & 50 & 0.22 & -- & 0.01 \\ 50 & 20 & 0.22 & -- & 0.01 \\ 50 & 20 & 0.44 & - & 0.01 \\ 50 & 20 & 0.88 & - & 0.0 \mathrm{I} \\ 50 & 20 & 1.54 & - & 0.0 \mathrm{I} \\ 50 & 20 & 0.22 & 2 & 0.01 \\ 50 & 20 & 0.22 & - & -\end{array}$

\begin{tabular}{|c|c|c|c|}
\hline \multicolumn{4}{|c|}{ Regeneration $(\%)$} \\
\hline \multicolumn{2}{|c|}{$\begin{array}{l}\text { Streptomyces } \\
\text { griseus }\end{array}$} & \multicolumn{2}{|c|}{$\begin{array}{l}\text { Streptomyces } \\
\text { venezuelae }\end{array}$} \\
\hline 3 days & 5 days & 5 days & 7 days \\
\hline 0.4 & 0.4 & 2 & 2 \\
\hline 8 & 37 & 27 & 32 \\
\hline 25 & $3 I$ & 3 & 3 \\
\hline 19 & $4 \mathrm{I}$ & 44 & 47 \\
\hline 28 & 37 & 50 & $5 I$ \\
\hline 38 & 48 & 44 & 47 \\
\hline 33 & 43 & 38 & 39 \\
\hline 0.4 & 10 & 7 & 12 \\
\hline 28 & 36 & 50 & 53 \\
\hline 0.4 & $3 I$ & 2 & 37 \\
\hline
\end{tabular}

* Basal medium; sucrose, $\mathrm{I} 20 \mathrm{~g} ; \mathrm{K}_{2} \mathrm{SO}_{4}, 0.25 \mathrm{~g}$ : trace element solution, $2 \mathrm{ml}$; glucose, Io g; L-asparagine (for $S$. griseus), $2 \mathrm{~g}$, or L-proline (for $S$. venezuelae), $3 \mathrm{~g} ; 0.25 \mathrm{M}$-TES buffer (pH 7.2), $100 \mathrm{ml}$; agar, $22 \mathrm{~g}$; and distilled water to $\mathrm{I} l$.

$\dagger$ PPB: potassium phosphate buffer $(\mathrm{pH} 7)$.

concentration to $60 \mathrm{mM}$ allowed the protoplasts of both species to regenerate significantly. Increasing the $\mathrm{MgCl}_{2}$ concentration to $60 \mathrm{mM}$, on the other hand, did allow the protoplasts of $S$. griseus to regenerate, but not those of $S$. venezuelae. With higher concentration of both $\mathrm{MgCl}_{2}$ and $\mathrm{CaCl}_{2}$, the reversion rate in $S$. griseus protoplasts was $4 \mathrm{I} \%$ in a combination of $20 \mathrm{mM}-\mathrm{MgCl}_{2}$ and $50 \mathrm{mM}-\mathrm{CaCl}_{2}$, and the rate for $S$. venezuelae was $5 \mathrm{I} \%$ in a combination of $50 \mathrm{mM}-\mathrm{MgCl}_{2}$ and $20 \mathrm{mM}-\mathrm{CaCl}_{2}$. The reversion rates obtained by these combinations of the divalent cations were reproducible. Usual concentrations of potassium phosphate buffer inhibited the reversion of the protoplasts of the two species, and adjusting the buffer concentration to 0.44 or $0.22 \mathrm{~mm}$ allowed them to regenerate significantly. In media without added Casamino acids, growth rate of the revertants was markedly delayed in both species, and the reversion rate was apparently reduced in $S$. venezuelae. From these results, two media, RI and R2, were established for reverting the streptomycete protoplasts (Table I).

\section{Phase-constant microscopy of reverting protoplasts}

The Streptomyces griseus protoplasts suspended in medium $\mathbf{P}$ were $\mathbf{I}$ to $2 \mu \mathrm{m}$ in diameter (Fig. 4a). Such protoplasts, incubated on medium RI, increased to about $30 \mu \mathrm{m}$ after $40 \mathrm{~h}$ (Fig. $4 b$ ). During the next $8 \mathrm{~h}$, most of the enlarged protoplasts continued to expand and regenerated filamentous hyphae from their periphery (Fig. $4 c, d$ ). The number of hyphae increased after $65 \mathrm{~h}$ (Fig. $4 e, 5 a, b$ ), though some enlarged protoplasts did not form any filamentous growth (Fig. $5 b$ ). After 73 h, the hyphae showed extensive branching (Fig. 6). A similar reverting process was observed in the protoplasts of $S$. venezuelae. 

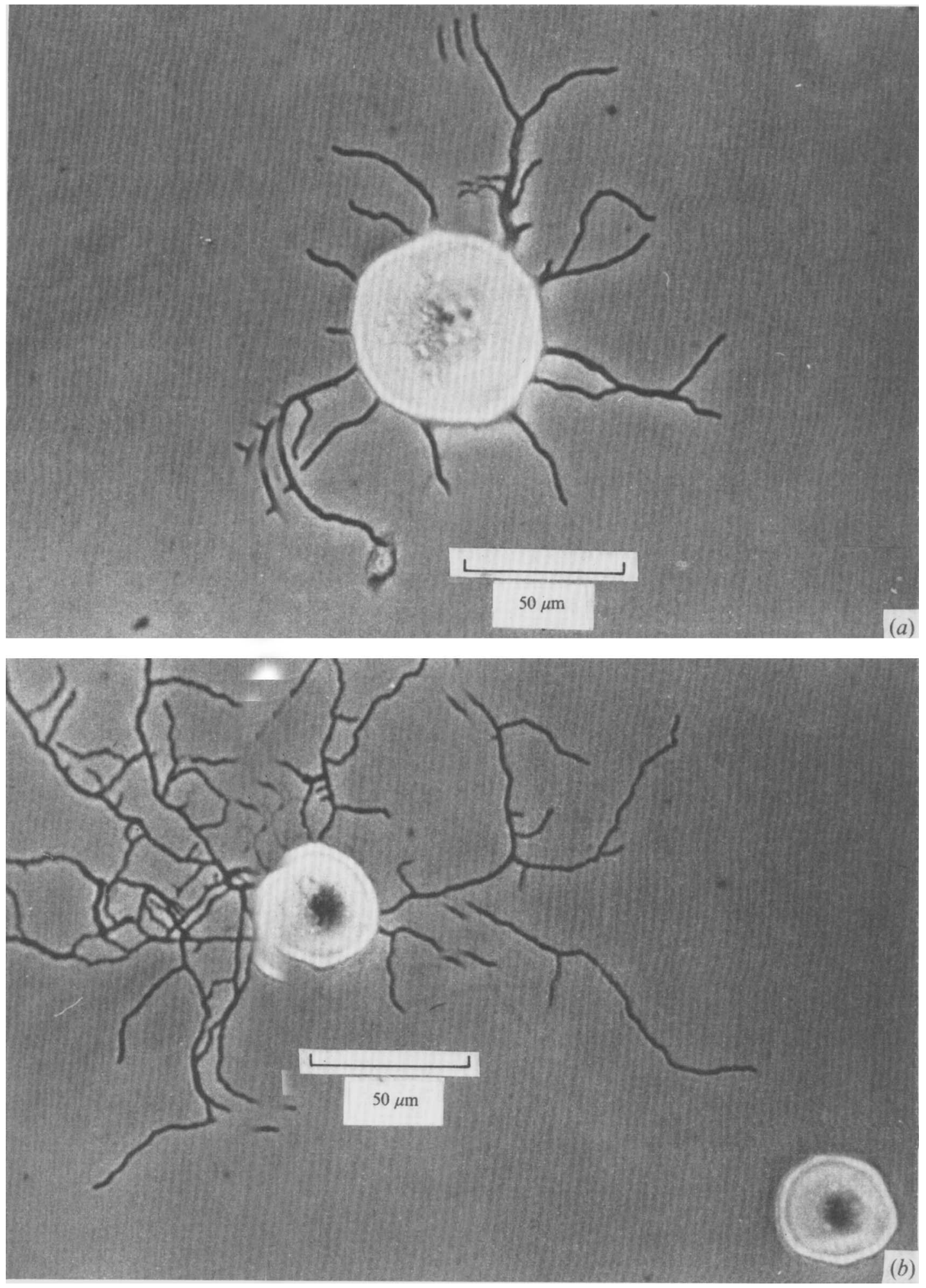

Fig. 5. Reverting process of Streptomyces griseus protoplasts on medium RI, under phase-contrast microscopy, $65 \mathrm{~h}$ after incubation. 


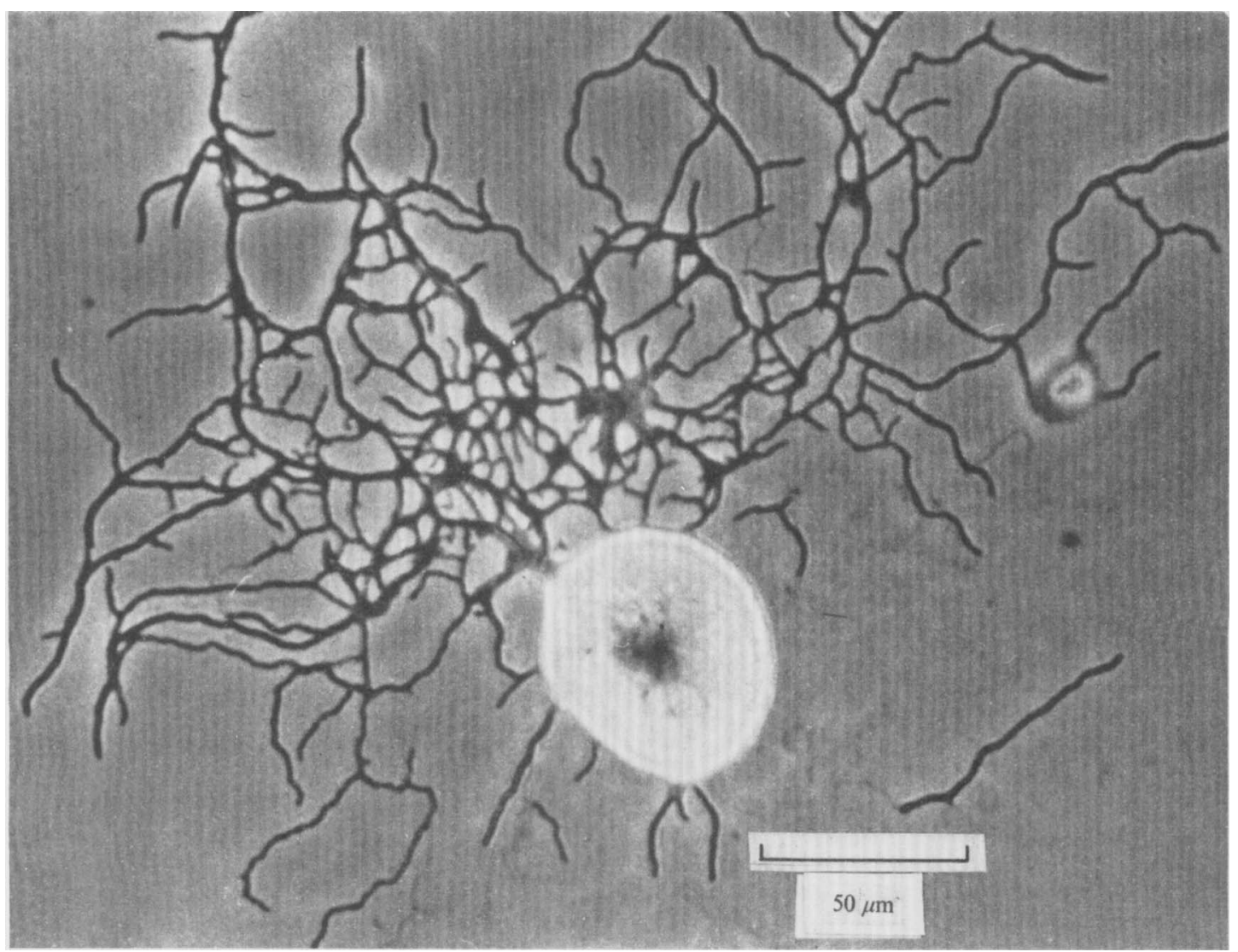

Fig. 6. Reverting process of Streptomyces griseus protoplasts after $73 \mathrm{~h}$ on medium RI.

\section{DISCUSSION}

Weibull (1956) suggested that the effect of $\mathrm{Mg}^{2+}$ on the stabilization of sphaeroplasts might be related to the prevention of release of lipid residues from the plasma membrane. Subsequently, $\mathrm{Mg}^{2+}$ has been employed by many researchers for stabilizing sphaeroplasts or protoplasts (e.g. Muschel, I968). Tabor (1962), on the other hand, reported that $\mathrm{Ca}^{2+}$ as well as spermine prevented lysis of lysozyme-induced protoplasts of Escherichia coli and Micrococcus lysodeikticus in hypertonic media. According to Reaveley \& Rogers (I969), the liberation of the vesicles of the mesosomes from protoplasts of Bacillus licheniformis was controlled by the $\mathrm{Mg}^{2+}$ concentration present during the removal of the walls by lysozyme, and the functioning of the cytoplasmic membranes was also critically controlled by $\mathrm{Mg}^{2+}$ concentration. Our experiments show that the combination of $10 \mathrm{mM}-\mathrm{MgCl}_{2}$ and 25 $\mathrm{mM}-\mathrm{CaCl}_{2}$ is effective for preparing and stabilizing the protoplasts of streptomycetes in hypertonic solutions. It was also found, by electron microscopy, that the protoplasts prepared with $10 \mathrm{mM}-\mathrm{MgCl}_{2}$ and $25 \mathrm{mM}-\mathrm{CaCl}_{2}$ had vesicles attached to, or released from, the cytoplasmic membrane. Those prepared with $3 \mathrm{mM}-\mathrm{MgCl}_{2}$ and $3 \mathrm{mM}-\mathrm{CaCl}_{2}$ exhibited few vesicles. Disappearance of the mesosomes with a lamella-like structure has already been observed by Sagara et al. (197I) in the protoplasts of Streptomyces griseoflavus. The fine 
structure of the mesosomes extruded from lysed cells of Bacillus subtilis in hypertonic medium has been observed by Ryter (r968).

Miller, Wiebe \& Landman (I968) and Landman, Ryter \& Fréhel (1968) reported that L bodies or protoplasts of Bacillus subtilis placed in $25 \%$ gelatin medium formed bacillary colonies. A similar effect of gelatin had been reported earlier by Nečas (I96I) in the reversion of Saccharomyces cerevisiae protoplasts. In our experiments, we were particularly interested in determining suitable methods for producing stable protoplasts and in the composition of a synthetic agar medium allowing reversion to the mycelial state for use in transformation studies. High reversion rates were obtained by incubating the protoplasts on the surface of a

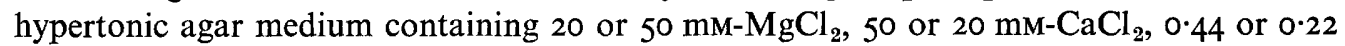
mM-phosphate and $0.01 \%$ Casamino acids. The combination of appropriate concentrations of $\mathrm{MgCl}_{2}$ and $\mathrm{CaCl}_{2}$ was effective in the reversion as well as in the stability of protoplasts. The concentration of phosphate at $0.44 \mathrm{~mm}$ or less was unexpectedly found to be important, and the addition of $0 \cdot \mathrm{I} g$ of Casamino acids/l enhanced the growth and reversion rates. The reasons for the requirement of these ingredients are not known.

The authors are indebted to Dr T. Nara of Kyowa Hakko Kogyo Co., Japan, for Lytic enzyme no. 2.

\section{REFERENCES}

Bradley, S. G. (1959). Protoplasts of Streptomyces griseus and Nocardia paraguayensis. Journal of Bacterio$\log y 77,115-116$.

Douglas, R. J., Robinson, J. B. \& CoRke, C. T. (I958). On the formation of protoplast-like structures from Streptomycetes. Canadian Journal of Microbiology 4, 55 I-554.

Ghosh, B. K. \& Murray, R. G. E. (1967). Fine structure of Listeria monocytogenes in relation to protoplast formation. Journal of Bacteriology 93, $4 \mathrm{I} \mathrm{I}-426$.

Good, N. E., Winget, D., Winter, W., Connolly, T. N., Izawa, S. \& Singh, R. M. M. (1966). Hydrogen ion buffers for biological research. Biochemistry $5,467-477$.

Kochina, Z. M. \& Rautenshtein, Y. I. (1968). Formation of protoplasts in Actinomyces streptomycini Krass. Microbiologiya 37, I046-I05I.

LANDMAN, O. E., RYTER, A. \& FRÉHEL, C. (1968). Gelatin-induced reversion of protoplasts of Bacillus subtilis to the bacillary form: electron-microscopic and physical study. Journal of Bacteriology 96, 2154-2170.

MilleR, I. L., Wiebe, W. \& LANDman, O. E. (1968). Gelatin-induced reversion of protoplasts of Bacillus subtilis to the bacillary form: photomicrographic study. Journal of Bacteriology 96, 217 I-2174.

Muschel, L. H. (1968). The formation of spheroplasts by immune substances and the reactivity of immune substances against diverse rounded forms. In Microbial Protoplasts, Spheroplasts and L-forms, pp. 19-29. Edited by L. B. Guze. Baltimore: Williams \& Wilkins.

NeČAS, O. (196I). Physical conditions as important factors for the regeneration of naked yeast protoplasts. Nature, London 192, 580-581.

OKanishi, M., Hamana, K. \& Umezawa, H. (1968). Factors affecting infection of protoplasts with deoxyribonucleic acid of actinophage PK-66. Journal of Virology 2, 686-691.

OKANISHI, M., UTAHARA, R. \& OKAMI, Y. (I966). Infection of the protoplasts of Streptomyces kanamyceticus with deoxyribonucleic acid preparation from actinophage PK-66. Journal of Bacteriology 92, I850-1852.

Reaveley, D. A. \& Rogers, H. J. (1969). Some enzymic activities and chemical properties of the mesosomes and cytoplasmic membranes of Bacillus licheniformis 6346. Biochemical Journal 113, 67-79.

RYTER, A. (1968). Association of the nucleus and the membrane of bacteria: a morphological study. Bacteriological Reviews 32, 39-54.

Sagara, Y., Fukui, K., Ota, F., Yoshida, N., Kashiyama, T. \& Fujimoto, M. (I97I). Rapid formation of protoplasts of Streptomyces griseoflavus and their fine structure. Japanese Journal of Microbiology $\mathbf{5}$. $73-84$.

TABOR, C. W. (1962). Stabilization of protoplasts and spheroplasts by spermine and other polyamines. Journal of Bacteriology 83, I IOI-I I I I.

Weibull, C. (1956). The nature of the 'ghosts' obtained by lysozyme lysis of Bacillus megaterium. Experimental Cell Research 10, 214-221. 